\title{
Living with Medieval Things: Why We Need a Global Medieval Archaeology
}

\author{
Kathryn Franklin* \\ Department of archaeology, University of Chicago Oriental Institute, USA
}

Submission: December 16, 2017; Published: May 07, 2018

*Corresponding author: Kathryn Franklin, Department of archaeology, University of Chicago Oriental Institute, 1155 E. $58^{\text {th }}$ St. Chicago IL 60637 , USA; Email: kathryn.j.franklin@gmail.com

\begin{abstract}
This essay argues for the critical relevance of medieval material culture to contemporary politics, and for the necessity of an engaged global medieval archaeology. Medieval things-material culture but also concepts and tropes-as they are imagined in the present hold a special place in the constitution of identity, and shape our ability to imagine difference in the world. The fault lies in the stories we have told ourselves in the west about the medieval period, the way that medieval stuff has been used to fuel dreams of modernity, progress, and civilization at the expense of their conceived opposites. This essay ultimately argues that for the sake of ourselves and our future, medieval archaeology needs to lead critical medievalism in the reclaiming of our things, and the retelling of better, more diverse medieval histories.
\end{abstract}

Keywords: Global medieval archaeology; Stuff; Things; Material politics; Post-colonial; Misuse of history; Mutual mapping; Material culture; Medieval historians; Tiki torches; Scummily; Archaeology; Natives; Phylogenetic

\section{Opinion}

2017 has demonstrated the continuing relevance of material culture, and of archaeology, to social life. In the US, as across the world, we saw our national and intimate politics play out through words and acts, but also in assemblages of things. The New York Times recently published "The Year in Stuff," a fashion-oriented account of the last twelve months in innocuous objects-a pink knit hat, a white terry cloth bathrobe-- put in the spotlight of national bodily politics [1]. In frankly archaeological ways, things were used to symbolize cultures, values, ways of living that were clashing in public-and this year we saw inanimate things, from TicTacs $^{\mathrm{TM}}$ to Tiki torches, take to social media to earnestly protest being taken out of context [2]. To be engaged in the social sphere currently means to be a spectator of participant in thing-politics, or the mutual mapping of power across people and their objects.

I am a medieval archaeologist, and my work focuses on the ways that material culture mediated imaginaries of distance and difference within the spheres of shared culture that we now call the Silk Road. I, and other scholars of medieval things, have found ourselves uncomfortably relevant recently, as the contents of our research has spilled out of shelves, drawers, and archives into the content of the 24-hour news cycle, or into the content of memes, floating scummily like toxic flotsam on the internet. In myriad ways, we clearly still live in the world(s) built in the middle ages; we literally and figuratively dwell in a storeroom of medieval stuff, from literary tropes to laws, buildings, furniture, foodstuffs, ways of dress, ways of imagining our best and worst selves. To trace the medieval in the modern has attained a critical relevance in the last few months, as medieval historians realize that things of the middle ages like castles and knightly heraldry, valor and exotic romance are culturally central to struggles for legibility, equality and survival in the US and elsewhere. Young white men marching for white rights in Charlottesville in August and posting on alt-right and neo-Nazi forums use medieval stuffshields, armor, helmets, heraldic symbols, runes, crusader flagsto make themselves more real, more historically legible [3]. The medievalist David Perry described the uncanny feeling of seeing his own material passions-medieval architecture, literature and art-shared in white supremacist discussion boards [4]. Medievalists across disciplines united in condemnation of the "misuse of history" in the name of white supremacy [5]. At the same time, images of crusaders and their flags, armor and weapons continue to float around the Internet in protest against immigration into Europe and the US, material symbols of natives desires to return to an imagined simpler, nobler, purer prelapsarian medieval space-time.

Our dark dreams of the medieval period as pre modern, pretechnological, pre-complicated (read: pre-diverse, preplural, pre-global) underlay some of the most gut wrenching challenges of the last few years. Particularly striking has been the power of a material vision of a pre modern and pre-global middle ages as a way to radicalize young people to violence across cultural and religious lines. Analysts of the now-perhapsfading Islamic State in Syria have observed that they too have drawn on the symbolism of a pre-modern, orient list imaginary 
of medieval Islam to attract disaffected recruits, even while making material reference, in bodily praxis, clothing, coinage, and to the $7^{\text {th }}$ century in order to root their legitimacy in history [6]. ISIS has embraced a unity with medieval thing-politics in their destruction of "idols" (god-things) at Nimrud and the Mosul museum [7], even as the medieval has served as a point of reference for framing Islamic terror by ISIS and other groups as un modern and thus less real, less valid, by observers (Salman Rushdie notably called the religion which motivated the killing of Charlie Hebdo artists a "medieval form of unreason") [8].

The hospitality of medieval imagined space time to violent nationalism is not news: critical medievalists have demonstrated the co-creation of the medieval with the modern, evoking the secular rationality of our world as something like Walter Benjamin's Angel of History, balancing precariously on a pile of swept up medieval things barely covered by a rug. According to these arguments, we cannot materially think the modern state, the sovereign subject, the economy, modern love or war without defining reference to medieval times. Others have traced the threads of these medieval imaginaries into popular culture, arguing that the bones of our shared dreams-the stories we use to tell other stories-are themselves medieval $[9,10]$. How do we make spaces for material difference in a discipline based on a concept ("the medieval") which was from its origin rooted in antagonistic distinctions between modern civilized selves and pre modern, barbarian others? Spurred by events of this past year, medievalists in related disciplines are calling for a postcolonial exploration of difference in the past: this is a problem for medieval archaeologists, scholars of medieval things, to address.

It is time for a critical and global engaged medieval archaeology, for medieval archaeologists to come for their things. To be critical and global means to think about the structures of power underlying traditions of knowledge, to be global means that we cope with distance, make space for difference. In terms of critically thinking politics through medieval stuff we're definitely late to the party: adherents of the 'material turn' have been using medieval things for decades already as fodder for the paradigm of vibrant matter, from saints' bones thick with value to $9^{\text {th }}$ century stones that assemble $[11,12]$. A critical medieval stuff logy sets out to work in several modes. The first is archaeological: where does our medieval stuff come from? Can we excavate, literally and, following Foucault, discursively, the ways that our world is made of strata and structures of medieval stuff (in addition to more ancient stuff)?

The second mode is anthropological and literary: what was a world made of medieval stuff like, and how was it put together? How did it feel to live in? A third mode is speculative: if the medieval material world was put together and lived within in ways that are different from our modern-centric understandings, then perhaps we can re-assemble a world built substantially from medieval stuff in different ways, and ways that value difference. If we look at accounts of the world from the middle ages as neither fact nor apocrypha but as stories, this challenges us to think, how we might use our archaeological storehouse of medieval stuff to tell different stories? How might we, to crib Umberto Eco, dream a different medieval?

A global medieval is also critically relevant as we face the $21^{\text {st }}$ century with the knowledge that myths of progress have led our human society astray, and that we need different stories to make it out of this era alive. One of the critical challenges facing global citizens in the Anthropocene may be, how do we imagine vastness in space and time--- and once imagined, how do we get others to imagine with us, and to care? In this too, medieval archaeologists can tell better stories, looking closely at how people in the medieval world imagined difference in the weave of silk, the melt of spiced sugar on the tongue, the furs of strange beasts and sweet sounds of bizarre instruments. Just as a modern era of science was enumerated in phylogenetic specimens captured, stars tracked, and generations of sweet peas bred to unlock the secret of genes, so the breadth of the world was first understood in stuff. The material record of the medieval Silk Road tells just that story of imagination and shared inspiration, as a messily and incompletely shared but nonetheless culturally commensurate vision of the world circulated in architecture, art, cuisine, textiles, perfumes, techniques of the body and literary tropes of the self. Telling stories of a diverse medieval world is a task archaeologists share with our fellow medievalists, and an urgent one; the entrenched position within the discipline that 'things speak for themselves' is visibly false and tangibly dangerous. We might, however, defeat bleak totalitarian visions of the medieval past with the richness of new stories we tell with medieval things.

\section{Acknowledgement}

I want to thank the community of medievalists for their critical engagement in the last year (and before), and especially Malisha Dewalt at Medieval POC for doing so much of the work of assembling. This essay is a pause in an ongoing conversation with colleagues to whom I am very grateful: Ömür Harmanşah, Katie Kearns, Kathy Morrison, and Tony Lauricella. Thanks to Tyson Leuchter for initial comments.

\section{References}

1. Schneier M (2017) The year in stuff. The New York Times. Dec. 13, 2017

2. https://twitter.com/tictacusa/status/784831611531436032?lang=en

3. Sturtevant P (2017) Leaving "medieval" Charlottesville: race, racism and the middle ages. The Public Medievalist. August 17, 2017.

4. Perry D (2017) What to do when Nazis are obsessed with your field: how medieval historians can counter white supremacy. Sept. 6, 2017.

5. Statement from the UVA Program in Medieval Studies following the events in Charlottesville:

6. Wood G (2014) The three types of people who fight for ISIS: a breakdown of the most evil group on the planet. The New Republic. September 10, 2014. 
7. Harmanşah Ö (2015) ISIS, heritage and the spectacles of destruction in the global media. Near Eastern Archaeology 78(3): 170-77.

8. Feeney N (2015) Salman Rushdie says, "I stand with Charlie Hebdo" after Paris attack. Time.

9. Davis K (2008) Periodization and sovereignty. Philadelphia: University of Pennsylvania Press.

10. Eco U (1986) Dreaming of the middle ages. In: Weaver W (Eds.) Travels in Hyperreality, trans. New York: Harcourt Brace, USA.

his work is licensed under Creative Commons Attribution 4.0 License

DOI: 10.19080/GJAA.2018.03.555625
11. Geary P (1988) Sacred commodities: the circulation of medieval relics. In The Social Life of Things. Appadurai A (Eds.), Cambridge: Cambridge University Press. Pp. 169-194.

12. Latour B (2005) From realpolitik to dingpolitik, or how to make things public. In Latour B, Webel P (Eds.), Making things public: atmospheres of democracy. Catalogue of the show at ZKM. Cambridge: MIT Press.

\section{Your next submission with Juniper Publishers will reach you the below assets}

- Quality Editorial service

- Swift Peer Review

- Reprints availability

- E-prints Service

- Manuscript Podcast for convenient understanding

- Global attainment for your research

- Manuscript accessibility in different formats

( Pdf, E-pub, Full Text, Audio)

- Unceasing customer service

Track the below URL for one-step submission https://juniperpublishers.com/online-submission.php 